\title{
Acromegaly Associated with Mixed Pituitary Adenoma-Gangliocytoma and Rathke's Cleft Cyst
}

\author{
Karısık Hipofiz Adenomu-Gangliositom ve Ratbke Yarı̆̆ Kistiyle İlişkili \\ Akromegali
}

Negar AZARPIRA ${ }^{1}$, Sara PAKBAZ ${ }^{1}$, Simin TORABINEGHAD ${ }^{1}$, Javad MUSAVI ${ }^{1}$, Mohamad RAKEI ${ }^{2}$

${ }^{1}$ Shiraz University of Medical Sciences, Organ Transplant Research Center, Department of Pathology, Shiraz, Islamic Republic of Iran

${ }^{2}$ Shiraz University of Medical Sciences, Department of Neurosurgery, Shiraz, Islamic Republic of Iran

Corresponding Author: Negar AZARPIRA / E-mail: negarazarpira@yahoo.com

\begin{abstract}
Gangliocytoma of the pituitary gland is a rare lesion that often occurs in combination with pituitary adenomas and the exact origin is the subject of discussion. We report a rare case of an intrasellar mass of combined gangliocytoma/ pituitary adenoma coexistent with Rathke's cleft cyst. A 50-year-old female was admitted to our hospital with headache, mild acromegaly, and bitemporal hemianopsia. Histologically the tumor was composed of triphasic component of pituitary adenoma, clusters of ganglion cells and small cysts embedded in a variably dense neuropil substrate. Immunohistochemical analysis revealed the ganglion cells and adenoma cells were positive for synaptophysin and neurofilament. The lining of Rathke's cleft cyst was immunoreactive for cytokeratin 8. The exact pathogenesis of combined sellar pathology is not clear yet. However, a common stem/progenitor cell origin of both the adenomatous and neuronal component of these lesions has been suggested.
\end{abstract}

KEYWORDS: Sella, Gangliocytomas, Rathke's cleft cyst, Pituitary adenoma

öz

Hipofiz bezi gangliositomu sıklıkla hipofiz adenomlarıyla kombinasyon halinde görülen nadir bir lezyondur ve kesin kökeni belli değildir. Rathke yarığı kistiyle birlikte görülen kombine gangliositom/hipofiz adenomundan oluşan nadir bir intrasellar kitle bildiriyoruz. 50 yaşında bir kadın hastanemize baş ağrısı, hafif akromegali ve bitemporal hemianopsiyle yatırıldı. Histolojik olarak tümör, hipofiz adenomunun trifazik bileşeni, gangliyon hücreleri kümeleri ve değişken şekilde yoğun nöropil substratına gömülü küçük kistlerden oluşmaktaydı. İmmünohistokimyasal analiz gangliyon hücreleri ve adenom hücrelerinin sinaptofizin ve nörofilament için pozitif olduğunu gösterdi. Rathke yarığı kistini döşeyen tabaka sitokeratin 8 için immünoreaktifti. Kombine sellar patolojinin tam patolojisi henüz kesin değildir. Ancak bu lezyonlarda hem adenomatöz hem nöronal bileşenin ortak bir kök/progenitor hücre kökeni düşünülmektedir.

ANAHTAR SÖZCÜKLER: Sella, Gangliositomlar, Rathke yarığı kisti, Hipofiz adenomu

\section{INTRODUCTION}

Collision tumors are defined as histologically different tumors close to each other. A great variety of lesions such as neoplastic, vascular, congenital, or infectious/inflammatory lesions can be found in combination. The presence of a collision tumor in the sellar region represents a very rare event. A preoperative diagnosis is usually very difficult and cases present clinically and radiologically as pituitary adenomas. Histological studies confirm the definitive diagnosis. The pathogenesis of these rare lesions is still unknown. Most combinations include the coexistence of a pituitary adenoma and a cystic tumor, particularly a Rathke cleft cyst $(9,12)$.

The aim of this article was to report a gangliocytoma coexisting with a growth hormone $(\mathrm{GH})$ secreting pituitary adenoma and Rathke's cleft cyst. Clinicopathologic correlation and review of the literature are undertaken.

\section{CASE REPORT}

A 50-year-old woman with a history of diabetes mellitus was admitted to the neurosurgery department with chief complaint of headaches and visual disturbances since 2 months ago. Physical examination revealed signs of mild acromegaly. Bilateral temporal hemianopsia was detected on ophthalmologic examination. The patient was preoperatively evaluated by an endocrinologist. Serum triiodothyronine (T3), thyroxine (T4), thyroid-stimulating hormone (TSH), luteinizing hormone (LH), follicle-stimulating hormone (FSH), adrenocorticotrophic hormone (ACTH) and cortisol levels were normal. GH serum levels were elevated (15.7 $\mathrm{ng} / \mathrm{ml}$ ). Prolactin level was marginally increased at $30 \mathrm{ng} /$ $\mathrm{ml}$, $(145.0 \mathrm{ng} / \mathrm{ml}$; normal $2.5-20 \mathrm{ng} / \mathrm{ml})$. MRI studies of the sellar region were performed as sagittal and coronal planes and included T1-weighted sequences, T1-weighted images after administration of gadolinium (Gd) and T2- 
weighted images. The images showed an intrasellar mass and the lesion enhanced after Gd administration (Figure 1). A clinical diagnosis of pituitary adenoma was made and she was operated via the transsphenoidal approach. Loss of the inhibitory effect of hypothalamic dopamine release due to tumoral "stalk effect" was suggested as an etiology of mild increased of prolactin level. After the operation, the patient's serum PRL level returned to normal $(7.6 \mathrm{ng} / \mathrm{ml})$.

Histologically, the sellar tumor was composed of three different parts. Pituitary adenoma, the major component, was composed of small cells with ovoid nuclei (Figure $2 A, B$ ). In the gangliocytoma, neuronal component with areas of abundant neurofibrillary background containing isolated or small clusters of ganglion cells were identified. Ganglion cells were defined as large cells with glassy cytoplasm and single or double nuclei with prominent nucleoli (Figure 3). Rathke's cleft cyst with single cell lining that contains colloidal material was also present. The cyst was lined by ciliated and/or cuboidal epithelial cells. No squamous epithelium was identified. Few psammomatous calcifications were present in stroma. There were no features suggesting aggressive behavior. Both ganglion cells and adenoma cells were immunoreactive for synaptophysin and neurofilament (Figure 4,5). Rathke's cleft cyst cell lining was immunoreactive for keratin 8 (Figure 6). The final diagnosis is mixed pituitary adenoma-gangliocytoma with Rathke's cleft cyst.

\section{DISCUSSION}

To our knowledge, our case is the first report of gangliocytoma co-existing with $\mathrm{GH}$-producing pituitary adenoma and Rathke's cleft cyst.

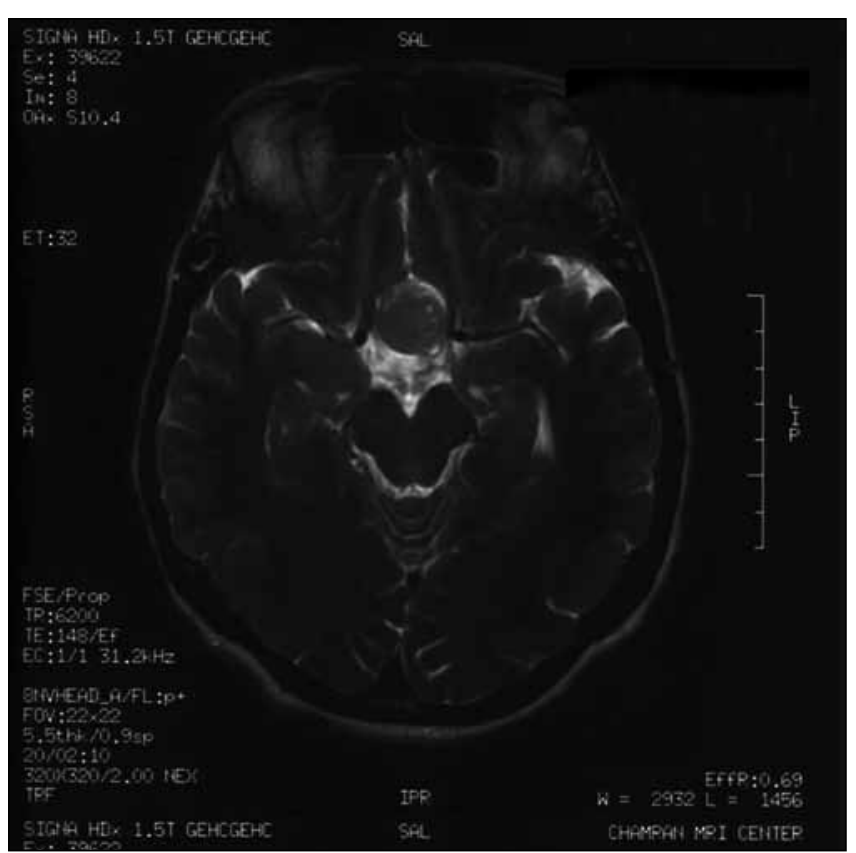

Figure 1: Coronal T1-weighted MRI showing a sellar mass.
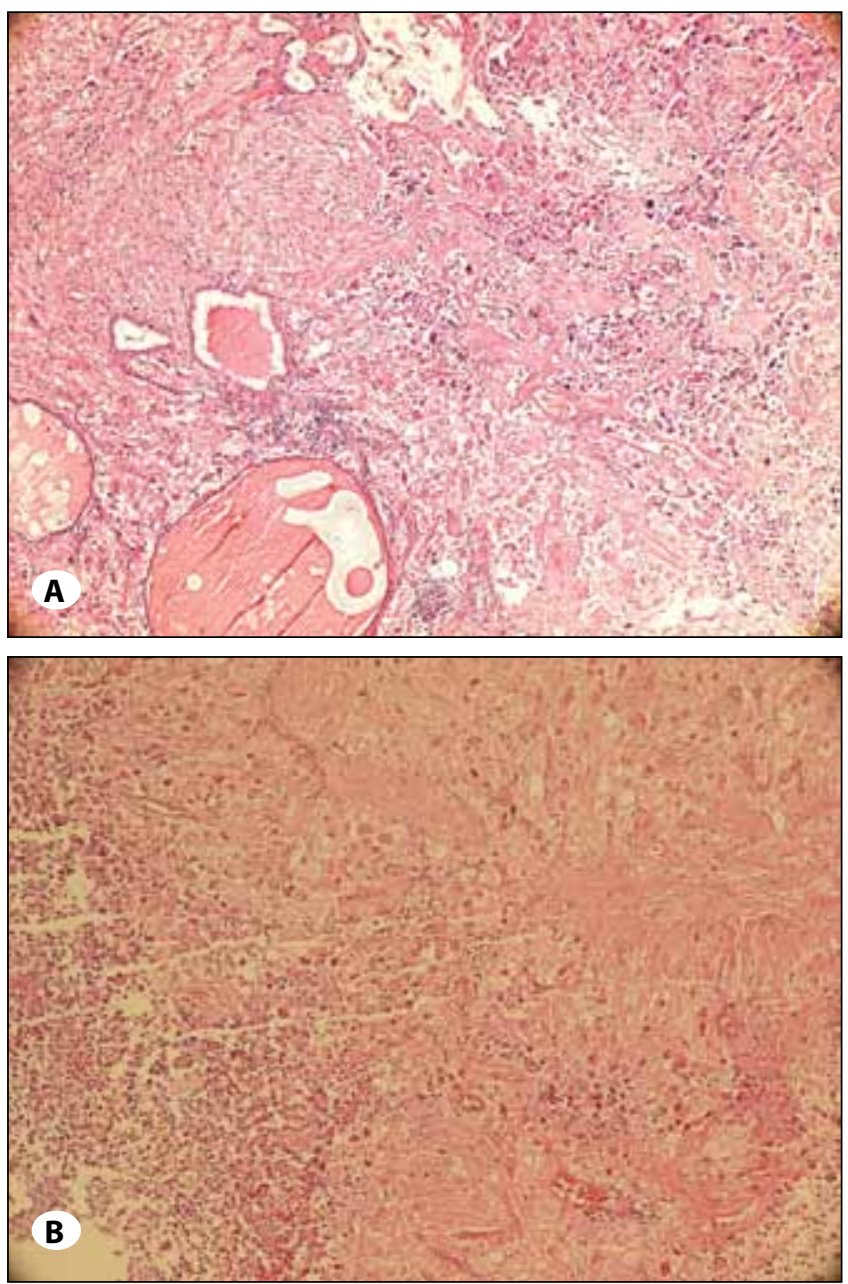

Figure 2A, B: Rathke's cleft cyst with single cell lining contains colloidal material. The surrounded tissue corresponds to pituitary adenoma /gangliocytoma $(\mathrm{H} \& \mathrm{E} \times 200)$.

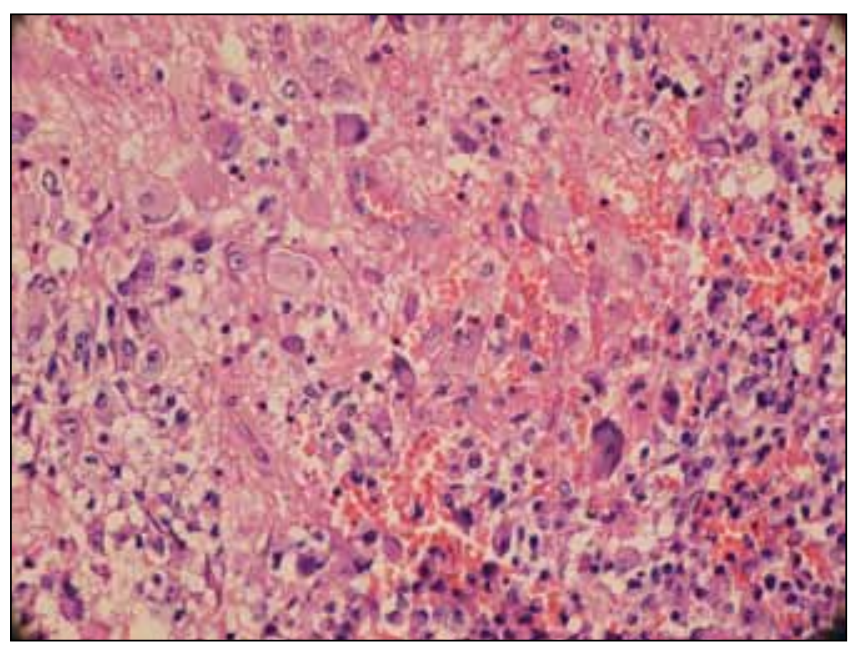

Figure 3: Gangliocytoma admixed with pituitary adenoma. The gangliocytic component contains large ganglion cells with abundant cytoplasm and prominent nuclei. (H\&E $\times 400)$. 


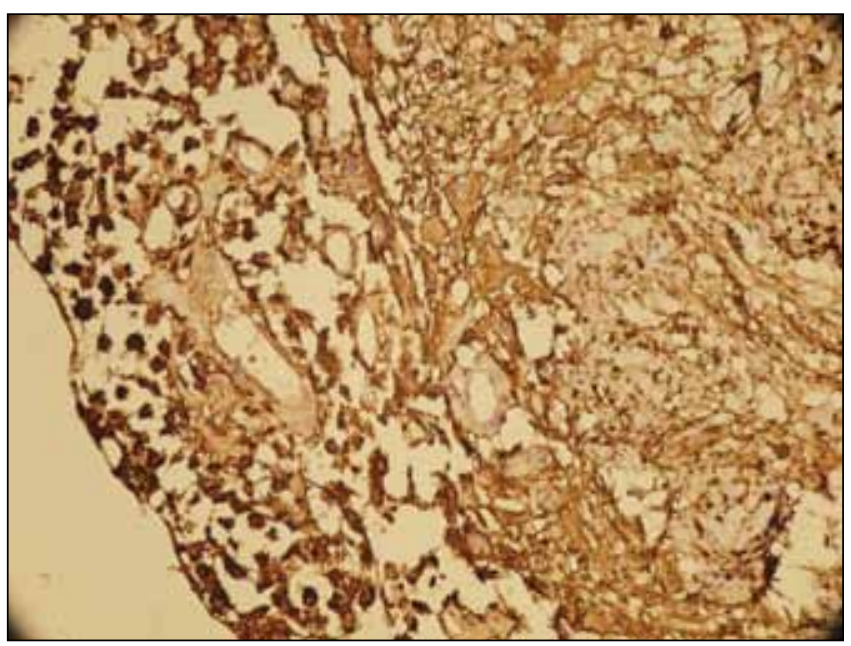

Figure 4: Synaptophysin immunostaining was observed both in the ganglions as well as adenoma cells $(\mathrm{IHC} \times 400)$.

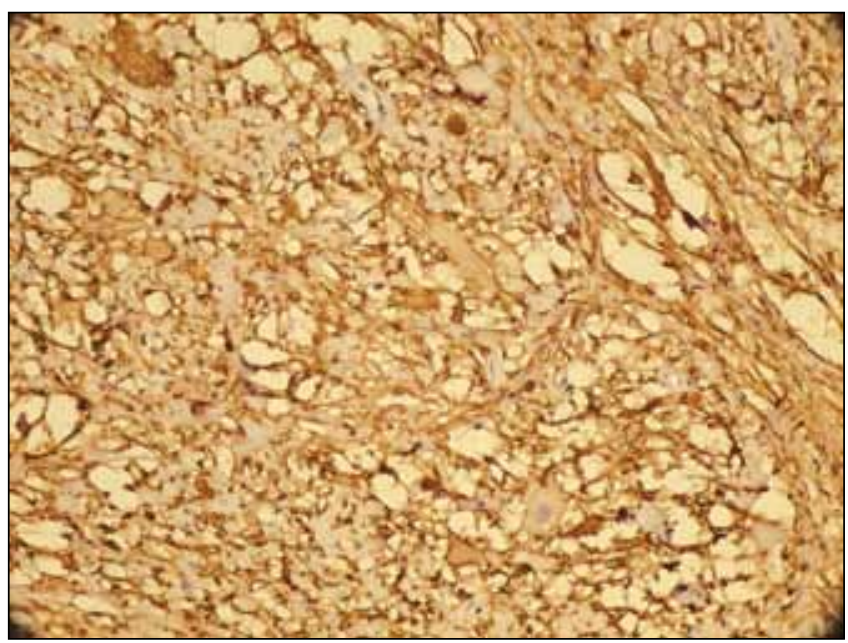

Figure 5: NF staining was positive in ganglion cells as well as intermingled adenoma cells (arrow) and fibrillary substrates $(\mathrm{IHC} \times 400)$.

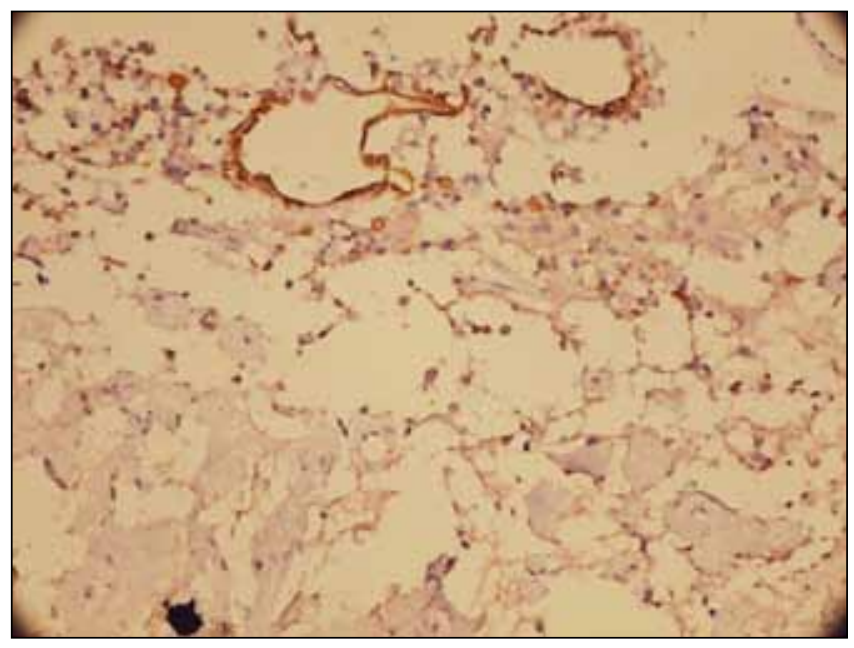

Figure 6: Rathke's cleft cyst with single low cuboidal cell lining immunoreactive for keratin 8 . The surrounded tissue corresponds to gangliocytoma. (IHC $\times 400)$.
To our knowledge, approximately less than 80 cases of pituitary adenomas containing ganglions have been reported $(9,11,12)$. The other synonyms are mixed pituitary adenomagangliocytoma, gangliocytoma with pituitary adenoma, pituitary adenoma with neuronal metaplasia (gangliocytoma), and pituitary adenoma with neuronal choristoma (PANCH). The majority of patients was females and preoperatively diagnosed as pituitary adenoma $(1,7,8,13,14,17,19,21,223,24)$. Few cases reported with symptoms of Cushing's disease or excessive PRL secretion $(2,8,15,20,24)$.

A number of reports of Rathke's cleft cysts coexisting with pituitary adenomas have been also published in English literature $(4,7,16,18,22)$, that the majority of them were prolactinomas (15). A smaller number were $\mathrm{GH}$-secreting $(5,17,21)$, corticotrophic (4), or nonfunctional adenoma (10). A mixed gangliocytoma-adenoma with ependymal component was also reported; which clinically presented with acromegaly and menstrual problems (25).

The tumor cells in pituitary adenomas have monoclonal nature. Molecular genetic alteration as either over- or underexpressed oncogenes, such as gsp, pituitary tumortransforming gene, p16 and the Gadd45y has been shown to participate in adenoma formation $(3,16)$.

Gangliocytomas are rare tumors with unknown histogenesis (12). Rathke's cleft cyst seems to be arising from remnants of Rathke's pouch $(4,5,16,18,22)$. The anterior and posterior walls of the pouch form the anterior and intermediate lobes of the pituitary gland. Normally obliteration of the duct occurs. If the lumen is not obliterated, a cyst forms between the anterior and posterior lobes of the pituitary $(5,16)$.

Several interesting hypotheses have been suggested to explain the histogenesis of different lesions in the sella. One theory suggested that abnormal migration of hypothalamic neurons within the adenohypophysial parenchyma was happen during the early phase of embryogenesis and pituitary adenoma developed with a preexisting neuronal choristoma (9). Another theory believed that an endocrine or paracrine stimulation of adenohypophysial cells by pituitary hormone- releasing hypothalamic hormones, which locally produced by ganglion cells of the neuronal component was responsible for pituitary adenoma formation (14). The third theory explained that the ganglion component originated from the neural differentiation of a preexisting pituitary adenoma (20). Towfighi et al. suggested that both neuronal and adenohypophysial cells originate from the same embryonal pituitary cell rests, showing intermediate features between neuronal and adenohypophysial elements (24).

The adult pituitary gland like other organs contains stem/ progenitor cell population (7). Kontogeorgos et al. (11) suggested that both neuronal and adenohypophysial components comes from uncommitted stem/progenitor cells that capable of multidirectional differentiation.

\section{CONCLUSION}

Collision sellar lesions in a patient operated for a pituitary 
adenoma is extremely rareand histological studies areessential to confirm the diagnosis. Although several hypotheses have been proposed to explain the histogenesis of these lesions, but the origin of this lesion has been the subject of discussion. In the future, progress in molecular pathology and further research on the mechanisms of pituitary tumorigenesis can explain the mechanisms.

\section{REFERENCES}

1. Asa SL, Scheithauer BW, Bilbao JM, Horvath E, Ryan N, Kovacs K, Randall RV, Laws ER Jr, Singer W, Linfoot JA, et al: A case for hypothalamic acromegaly: A clinicopathological study of six patients with hypothalamic gangliocytomas producing growth hormone-releasing factor. J Clin Endocrinol Metab 58:796-803,1984

2. Asa SL, Kovacs K, Tindall GT, Barrow DL, Horvath E, Vecsei P: Cushing's disease associated with an intrasellar gangliocytoma producing corticotropin-releasing factor. Ann Intern Med 101:789-793,1984

3. Asa SL, Ezzat S: The cytogenesis and pathogenesis of pituitary adenomas. Endocr Rev 19:798-827,1998

4. Arita K, Uozumi T, Takechi A, Hirohata T, Pant B, Kubo K, Tanaka $\mathrm{K}$ : A case of Cushing's disease accompanied by Rathke's cleft cyst: The usefulness of cavernous sinus sampling in the localization of microadenoma. Surg Neurol 42:112-116, 1994

5. Bader LJ, Carter KD, Latchaw RE, Ellis WG, Wexler JA, Watson JC: Simultaneous symptomatic Rathke's cleft cyst and GH secreting pituitary adenoma: A case report. Pituitary 7:39-44, 2004

6. Chen J, Hersmus N, Van Duppen V, Caesens P, Denef C, Vankelecom $\mathrm{H}$ : The adult pituitary contains a cell population displaying stem/progenitor cell and early embryonic Characteristics. Endocrinology 146:3985-3998, 2005

7. Geddes JF, Jansen GH, Robinson SF, Gömöri E, Holton JL, Monson JP, Besser GM, Révész T: "Gangliocytomas" of the pituitary. A heterogeneous group of lesion with differing histogenesis. Am J Surg Pathol 24:607-613, 2000

8. Horvath E, Kovacs K, Scheithauer BW, Lloyd RV, Smyth HS: Pituitary adenoma with neuronal choristoma (PANCH). Composite lesion or lineage infidelity? Ultrastruct Pathol 18:565-574, 1994

9. Karavitaki N, Scheithauer BW, Watt J, Ansorge O, Moschopoulos M, Llaguno AV, Wass JA: Collision lesions of the sella: Co-existence of craniopharyngioma with gonadotroph adenoma and of Rathke's cleft cyst with corticotroph adenoma. Pituitary 11:317-323, 2008

10. Kim JE, Kim JH, Kim OL, Paek SH, Kim DG, Chi JG, Jung HW: Surgical treatment of symptomatic Rathke cleft cysts: Clinical features and results with special attention to recurrence. J Neurosurg 100:33-40, 2004

11. Kontogeorgos G, Mourouti G, Kyrodimou E, Liapi-Avgeri G, Parasi E: Ganglion cell containing pituitary adenomas: Signs of neuronal differentiation in adenoma cells. Acta Neuropathol 112:21-28, 2006
12. Koutourousiou $M$, Kontogeorgos $G$, Wesseling $P$, Grotenhuis AJ, Seretis A: Collision sellar lesions: Experience with eight cases and review of the literature. Pituitary 13:8-17,2010

13. Kurosaki M, Saeger W, Lüdecke DK: Intrasellar gangliocytomas associated with acromegaly. Brain Tumor Pathol 19:63-67, 2002

14. LiY, Racadot O, Kujas M, Kouradri M, Pleion F, Racadot J: Immunocytochemistry of four pituitary adenomas and intrasellar gangliocytomas associated with different clinical syndromes: Acromegaly, amenorrhea-galactorrhea, Cushing's disease and isolated tumoral syndrome. Acta Neuropathol 77:320328,1989

15. Melmed S: Mechanisms for pituitary tumorigenesis: The plastic pituitary. J Clin Invest 112:1603-1618, 2003

16. Miyagi $A$, Iwasaki $M$, Shibuya $T$, Kido $G$, Kushi $H$, Miyagami M, Tsubokawa T: Pituitary adenoma combined with Rathke's cleft cyst-case report. Neurol Med Chir (Tokyo) 33:643-650, 1993

17. Nakamura $M$, Abe $Y$, Hatanaka $H$, Tsutsumi $Y$, Kijima $H$, Ueyama $\mathrm{Y}$, Inoue $\mathrm{H}$, Shimosato $\mathrm{Y}$, Osamura RY: Bronchial carcinoid tumor with gangliocytic- and paraganglionlike differentiation. Virchows Arch 442:183-185, 2003

18. Nishio S, Fujiwara S, Morioka T, Fukui M: Rathke's cleft cysts within a growth hormone producing pituitary adenoma. $\mathrm{Br} \mathrm{J}$ Neurosurg 9(1):51-55, 1995

19. Puchner MJ, Lüdecke DK, Saeger W, Riedel M, Asa SL: Gangliocytomas of the sellar region-a review. Exp Clin Endocrinol Diabetes 103(3):129-149, 1995

20. Puchner MJ, Lüdecke DK, Valdueza JM, Saeger W, Willig RP, Stalla GK, Odink RJ: Cushing's disease in a child caused by a corticotropin-releasing hormone-secreting intrasellar gangliocytoma associated with an adrenocorticotropic hormone-secreting pituitary adenoma. Neurosurgery 33:920-924, 1993

21. Saeger W, Puchner MJ, Lüdecke DK: Combined sellar gangliocytoma and pituitary adenoma in acromegaly or Cushing's disease. A report of three cases. Virchows Arch 425:93-99, 1994

22. Sumida M, Migita K, Tominaga A, lida K, Kurisu K: Concomitant pituitary adenoma and Rathke's cleft cyst. Neuroradiology 43:755-759, 2001

23. Sy J, Ang LC: Cytomorphologic spectrum of mixed pituitary adenoma-gangliocytomas: A report of two cases. Acta Cytol 54: 981-984, 2010

24. Towfighi J, Salam MM, McLendon RE, Powers S, Page RB: Ganglion-cell-containing tumors of the pituitary gland. Arch Pathol Lab Med 120:369-377, 1996

25. Xiao P, Xue L, Peng JJ, Feng ST, Liao B, Wen JM: An intrasellar mixed gangliocytoma-adenoma including ependymal component, and review of the literature. BMJ Case Rep 2009: bcr11 .2008. 1200, 2009 